\title{
Public Participation in Decision-Making About Forests \\ La participation du public dans la prise de décision touchant les forêts
}

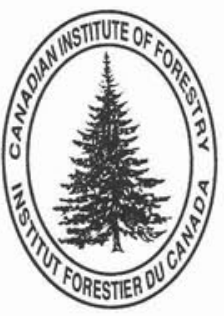

\section{Position Paper/Énoncé de Politique \\ Canadian Institute of Forestry/Institut forestier du Canada}

\section{Introduction}

Until recently, forest decision-making in Canada was carried out mainly by professional forest managers employed by timber tenure holders and by government. As in other areas of resource development, citizens everywhere are playing an increasingly meaningful direct role in forest decision-making. There are many reasons for this. For most public-policy issues, citizen participation has become an accepted element of decision-making. As the demands on forests increase, opportunities for conflict also increase. The Canadian public owns about $90 \%$ of the country's forests, and therefore has responsibilities and rights to participate in determining their future. Public participation may be defined as any situation where people other than resource-management professionals and tenure holders in forest decision-making are invited to give opinions on any matter in the decision process. There is a wide variety of degrees of public participation, and also of techniques and forms of participation. Public participation includes everything from surveys and open houses to full decision-making partnerships. There is concern, however, that mechanisms for public input in forest decision-making still require strengthening and further development.

\section{Importance \\ Conflict over the management and use of public forests exists across Canada. Often these conflicts arise among forest users, but they also arise between users and, urban-based environ- mental organizations and citizens. Sometimes conflicts are ben- eficial, helping people reject bad ideas and focus direction. How- ever, usually they are destructive and harmful, especially when communities become divided into bitter factions. Pro- ductive public involvement in forest decision-making can, on one hand, prevent unnecessary conflict, and, on the other, chan- nel existing and new conflicts into collaborative searches for accommodating solutions.}

\section{Opportunities}

Forest managers and policy-makers have ample opportunity for creating and implementing public participation exercises in forest decision-making. Planning exercises for public forests are undertaken every five or ten years for each forest (depending on the province), and represent the most common context for public input. However, regional land-use strategies and provincial and national policy-development processes are also prime opportunities for engaging the public productively in forest decision-making. Recently, even private forest owners are realizing that careful involvement of the local pub-

\section{Introduction}

Jusqu'à récemment, la prise de décision en matière de forêts au Canada se prenait principalement par les gestionnaires forestiers professionnels à l'emploi des détenteurs de droits d'exploitation forestière et du gouvernement. Comme pour les autres domaines de développement des ressources, les citoyens dans toutes les régions jouent de plus en plus un rôle direct significatif dans la prise de décision en matière de forêts. Il existe plusieurs raisons expliquant ce phénomène. Pour la plupart des enjeux politiques et publiques, la participation publique est devenue un élément intégrant du processus de prise de décision. À mesure que la demande rattachée aux forêts s'accrôt, les possibilités de conflits deviennent également plus nombreux. Les Canadiens détiennent publiquement près de $90 \%$ des forêts du pays, et en conséquence, ont des responsabilités et des droits de participation sur l'orientation de leur avenir.

La participation publique peut être définie comme étant toute situation où des personnes autres que les professionnels responsables de l'aménagement des ressources et les détenteurs de droits d'exploitation lors d'une prise de décision en matière de forêts sont invitées à partager leurs opinions sur tous sujets affectés par la prise de décision. Il existe un grande variété de niveaux de participation publique, ainsi que de techniques et de formes de participation. La participation publique comprend tous les éléments allant des sondages aux sessions portes-ouvertes jusqu'au partenariat complet dans la prise de décision. Cependant, il semble que les mécanismes d'intégration des intrants publiques dans la prise de décision demandent encore à être renforcer et nécessitent plus de recherche.

\section{Importance}

Le conflit sur la gestion et l'utilisation des forêts publiques est commun à tout le Canada. Souvent les conflits surgissent entre les utilisateurs des forêts, mais quelques fois entre les utilisateurs et les organisations et les citoyens issus des milieux urbains. Ces conflits sont parfois bénéfiques, permettant aux gens de rejeter les mauvaises idées et de définir la direction à suivre. Toutefois, habituellement ils sont destructifs et entraînent des blessures, surtout lorsque les communautés se divisent en factions opposées. La participation publique productive dans la prise de décision sur les forêts peut, d'un autre côté, prévenir les conflits inutiles, et, par ailleurs, rediriger les conflits existants ainsi que les nouveaux vers la recherche en collaboration de solutions acceptables.

\section{Opportunités}

Les gestionnaires forestiers et les législateurs ont souvent la possibilité de créer et d'implanter des exercices de partic- 
lic in forest planning can improve public relations and possibly even increase the revenues generated from the private lands.

\section{Current Status}

During the 1990s, public participation has found its way into forest decision-making in Canada at all levels. The public is involved in provincial and national forest-policy discussions and debates as well as local public-land forest-management planning exercises. Public participation is still maturing in practice, but the principle is now embraced in virtually all jurisdictions for all decision-making levels. Implementation of open and transparent processes is occurring everywhere, and practice is developing rapidly as people experiment with different techniques.

\section{Rights and Responsibilities}

Forest owners have the right to manage their lands for their own objectives, and have the responsibility to involve in decision-making all persons who may be significantly affected by such management. For lands in public ownership, agency managers have the responsibility to ensure that interested citizens have ample opportunity to make meaningful input into forest decision-making at all levels.

Citizens, for their part, have the right to become involved in forest decision-making for public-land forests. With this, though, comes the responsibility to become adequately prepared to make meaningful input. Resource professionals have the responsibility to provide timely, unbiased and relevant information for public deliberations. All parties have the responsibility to work together constructively in searching for innovative solutions to forest management problems.

\section{Promising Future Directions}

It is possible to foresee full implementation of effective and efficient processes for public participation at all levels of decision-making, from local forest-management plans through regional and municipal land-use strategies to provincial and national policy-making. We can expect to witness a growing maturity of practice led by creative process designers and implementers who will experiment with various techniques, and fed by continuous sharing of successes and failures through an active network of practitioners and participants. Doubtless there will be continued emphasis on group-oriented processes, complemented by a continued reaching out to any members of the public who want to contribute. Some public advisory groups will demonstrate sufficient maturity and willingness to assume higher degrees of responsibility, and will begin sharing decision-making roles with professionals and agency officials.

Public participation in forest decision-making in Canada is rapidly moving through its adolescence. While many issues still remain to be resolved, the signs are bright for a long and productive maturity. Forestry professionals are displaying a welcome openness and considerable energy for acquiring public advice on their decisions. The pursuit of forest sustainability can only be enhanced with such promising directions.

\section{CIF/IFC Positions}

The CIF/IFC fully endorses the concept of public participation in forest decision-making. It supports the following attributes of such participation: (a) a balance of inputs; (b) an ipation publique lors de la prise de décision sur les forêts. Les exercices de planification touchant les forêts publiques sont entrepris tous les cinq ou dix ans pour chaque forêt (selon la province), et représente le contexte le plus courant permettant de recueillir les intrants du public. Toutefois, les stratégies régionales d'utilisation du territoire ainsi que les processus provinciaux et nationaux d'élaboration de politiques sont également des opportunités de premier choix pour engager le public de façon productive dans la prise de décision sur les forêts. Dernièrement, même les propriétaires de boisés privés ont réalisé que l'implication adéquate du public local en matière de planification forestière peut améliorer les relations avec le public et probablement même accroître les revenus tirés des forêts privées.

\section{Situation actuelle}

Au cours des années 90, la participation publique a pris sa place dans les processus de prise de décision sur les forêts au Canada et à tous les niveaux. Le public participe aux discussions de politiques forestières au niveau provincial et national et questionne aussi bien les exercices locaux de planification de l'aménagement forestier sur les terres publiques. La participation publique continue d'acquérir de l'expérience dans la pratique, mais le principe maintenant couvre pratiquement dans toutes les juridictions l'ensemble des niveaux de prise de décision. L'implantation de processus accueillants et transparents se poursuit partout, et la pratique devient courante alors que des personnes mettent à l'essai différentes techniques.

\section{Droits et responsabilités}

Les propriétaires forestiers ont le droit de gérer leurs terres selon leurs propres objectifs, et ont la responsabilité d'impliquer dans la prise de décision toutes les personnes qui pourraient être significativement affectées par les aménagements retenus. Pour les terres de propriété privée, les gestionnaires gouvernementaux ont la responsabilité de s'assurer que les citoyens intéressés ont amplement l'occasion d'apporter une contribution significative à la prise de décision sur les forêts et cela à tous les niveaux.

Les citoyens, de leur côté, ont le droit d'être inclus dans la prise de décision sur les forêts des terres publiques. Avec ce droit, en conséquence, vient la responsabilité d'être adéquatement préparé pour apporter une contribution significative. Les professionnels des ressources ont la responsabilité de fournir de l'information non biaisée et pertinente dans des délais acceptables pour être débattue en public. Toutes les parties ont la responsabilité de travailler ensemble de façon constructive pour rechercher des solutions innovatrices aux problèmes de gestion forestière.

\section{Orientations futures intéressantes}

Il est possible de prévoir l'implantation complète de processus efficace et efficient de participation publique à tous les niveaux de prise de décision, allant des plans locaux de gestion forestière aux stratégies régionales et municipales d'utilisation du territoire et à l'élaboration de politiques provinciales et nationales. Nous pouvons nous attendre à être témoin de la croissance de l'expérience acquise par la pratique dirigée par des concepteurs de processus créatifs et des personnes chargées de l'implantation qui expérimenteront diverses techniques, et qui seront alimentées par le partage continu des succès et échecs 
informed public; (c) consistent with the concept of sustainable development, a strong consideration for future generations; (d) clear definition of the rights, responsibilities and roles of all parties; and (e) respect for legal rights of forest tenure holders; (f) which are consistent with the principles of national forest programs.

The CIF/IFC calls for establishment and implementation of:

- public participation for all levels of forest decisionmaking in processes that: (a) are proactive, open and fair; (b) help participants learn about the social, economic, ecological and technical aspects of forest management; (c) involve the public early and in all key planning functions and decisions, including process design; and (d) are flexible to permit local experimentation that fosters learning about promising approaches; and

- training programs for both resource professionals and lay citizens, aimed at raising skills and understanding of approaches and techniques for productive public participation in forest decision-making.

\section{WHO WE ARE}

The Canadian Institute of Forestry is a national, non-profit forestry organization. Our mission is to advance the stewardship of Canada's forest resources, provide national leadership in forestry, promote competence among forestry professionals, and foster public awareness of Canadian and international forestry issues.

We are people with a professional interest in forestry, working in government, industry, academic and consulting fields. Our members use their education, training, and experience to help manage the forests of Canada and to make the Canadian public aware of forestry.

This article is a statement of what we stand for - the Institute's position on Public Participation in Decision-Making About Forests.

Canadian Institute of Forestry/Institut forestier du Canada 151 Slater Street, Suite 606, Ottawa Ontario K1P 5H3

Telephone: 613-234-2242

Facsimile: 613-234-6181

Email: cif@cif-ifc.org

Internet: http://www.cif-ifc.org

Prepared by/Préparé par

Peter Duinker, Policy and Economics Working Group

Peter Duinker, Groupe de travail sur les politiques et l'économie

Approved: July 7, 1998

Approuvé: 7 juillet 1998 grâce à un réseau actif de praticiens et de participants. Sans doute, il y aura toujours de l'emphase sur les processus touchant les groupes, auquel s'ajoutera une recherche constante de tous les membres du public qui souhaitent participer. Certains groupes consultatifs publics démontreront suffisamment de maturité et de volonté pour assumer un plus haut niveau de responsabilité, et ils commenceront à partager les rôles de la prise de décision avec les professionnels et les fonctionnaires gouvernementaux.

La participation du public dans la prise de décision sur les forêts au Canada progresse rapidement à travers son adolescence. Même si quelques enjeux restent encore à résoudre, les signes de progrès vers une maturité longue et durable sont positifs. Les professionnels forestiers font preuve d'une saine ouverture et d'une énergie considérable pour recueillir le point de vue du public sur leurs décisions. La poursuite de la durabilité des forêts peut seulement qu'être vivifiée par de telles orientations.

\section{Le point de vue de l'Institut}

L'Institut forestier du Canada endosse totalement le concept de participation publique dans la prise de décision sur les forêts. Il appuie les élément suivants d'une telle participation: a) un équilibre dans les intrants; b) un public informé; c) l'alignement avec le concept de développement durable, une forte tendance à considérer les générations futures; d) une définition précise des droits, des responsabilités et des fonctions de toutes les parties; e) le respect des droits légaux des détenteurs de tenure forestière; et f) qui doivent être alignés sur les principes des programmes forestiers nationaux.

L'Institut fait appel à la mise en place et l'implantation de:

- la participation publique pour tous les processus de tous les niveaux de prises de décisions qui: a) sont proactif, ouvert et honnête; b) aident les participants à comprendre les aspects sociaux, économiques, écologiques et techniques de l'aménagement forestier; $\mathrm{c}$ ) impliquent le public dès le début et dans toutes les principales fonctions et décisions, y compris la conception du processus; et d) sont prêt à essayer localement des nouveautés qui susciteront plus de recherche sur les approches prometteuses; et

- des programmes de formation pour les professionnels de la ressource et les citoyens ordinaires qui viseront à accroître les habiletés et la compréhension des approches et des techniques de participation productive du public dans la prise de décision sur les forêts.

\section{CE QU'EST L'INSTITUT}

L'Institut forestier du Canada est une organisation forestière nationale sans but lucratif. Notre mission vise à faire progresser l'intendance des ressources forestières du Canada, assumer un leadership national en foresterie, à promouvoir la compétence au sein des professionnels de la foresterie, et à susciter la sensibilisation du public face aux enjeux forestiers canadiens et internationaux.

Nous sommes des personnes ayant un intérêt professionnel en foresterie, à l'emploi des gouvernements, de l'industrie, dans le domaine de l'enseignement et de la consultation. Nos membres se basent sur leur formation académique, leur formation technique et leur expérience pour aider à gérer les forêts $d u$ Canada et à sensibiliser le public canadien envers les forêts.

Ce document est un énoncé de ce que nous appuyons ( la position de l'Institut en matière de participation publique au cours de la prise de décision sur les forêts. 